\title{
Analiza sigurnosti pri radu u šumarstvu Federacije BiH - studij slučaja
}

\author{
Jusuf Musić, Velid Halilović, Ahmet Lojo, Mario Šporčić, Ajdin Đonlagić
}

\begin{abstract}
Nacrtak - Abstract
Ozljede na radu i profesionalne bolesti radnika pouzdan su indikator procjene stanja sigurnosti pri radu. Osnovni je cilj ovoga rada odgovarajuća analiza stanja sigurnosti pri radu u Javnom poduzeću Šumsko-privredno društvo Zeničko-dobojskoga kantona d.o.o. Zavidovići. Predmet su analize bile ozljede na radu, profesionalne i druge bolesti šumarskih radnika u razdoblju od 2006. do 2015. godine. Ozljede su analizirane prema deset pokazatelja. U analiziranom razdoblju zabilježene su 594 ozljede na radu, od čega tri smrtna slučaja. Najviše ozljeda dogodilo se neposrednim izvršiteljima radnih operacija pridobivanja drva $(66,3 \%$ ), a najrizičnija je profesija sjekač (57,7\% ). Predmet rada (drvo i grane) bili su najčešći materijalni uzrok ozljeda (49,3\%), a najčešće su ozlijeđeni ekstremiteti radnika - noge i ruke (70\%). Najveći broj ozljeda zabilježen je početkom radnoga tjedna i dana. Na osnovi broja ozljeda po obujmu izrađenoga drva (314/mil. $\left.m^{3}\right)$ te indeksa od 60 ozljeda na 1000 zaposlenika stanje sigurnosti pri radu može se ocijeniti kao iznimno nezadovoljavajuće.
\end{abstract}

Ključne riječi: ozljede na radu, šumarski radnici, profesionalne bolesti, zaštita na radu

\section{Uvod - Introduction}

Ozljeda na radu definira se kao iznenadni neočekivani događaj uzrokovan vanjskim utjecajem koji rezultira ozljeđivanjem radnika (Kulušić 2000). Pojam ozljede na radu poznat je gotovo koliko i ljudski rad, a prva zabilježena nesreća na radu koja je završila smrću dvaju rudara spominje se još prije više tisuća godina (Marković 1989). Pod profesionalnom bolešću smatra se patološko stanje koje nastaje zbog nepovoljnih utjecaja profesionalnih uvjeta i zahtjeva rada na radnom mjestu bolesnoga radnika (Čomić 1997). Uzroci tih bolesti vezani su uz tehnološki proces, uvjete na radu ili opće uvjete radnoga mjesta.

Šumarstvo, a posebno područje pridobivanja drva, jedan je od najopasnijih industrijskih sektora u većini zemalja. Specifični, teški i opasni radni uvjeti, karakteristike radnoga mjesta i predmeta rada, nepovoljan položaj tijela pri radu, trajanje i struktura radnoga vremena te energetska potrošnja rezultiraju time da su ozljede na radu kod radnika u šumarskoj proizvodnji češće u odnosu na gospodarstvo za oko 1,5 puta, a u odnosu na cjelokupnu djelatnost (gospodarstvo + društvene djelatnosti) za oko 1,7 puta (Čomić 1997). Iako ne postoje sistematizirani podaci, procjene govore da broj ozljeda u profesionalnom šumskom radu u svijetu prelazi 170000 godišnje (Garland 2018).

Također, profesionalne bolesti posebno su izražene kod radnika u šumarskoj proizvodnji. Stupanj pojavnosti invalidnih radnika u šumarstvu Bosne i Hercegovine, s potpunim gubitkom radne sposobnosti zbog profesionalnih bolesti, na prvom je mjestu. I u susjednoj Hrvatskoj, na primjer, broj profesionalnih bolesti u Hrvatskim šumama d.o.o. u odnosu na broj zaposlenih za 2009. godinu ima iznimno visok indeks od 2,08 profesionalnih bolesti na 1000 zaposlenih, što je daleko najviši indeks u odnosu na ostale gospodarske djelatnosti (Landekić 2010).

Negativno značenje ozljeda na radu i profesionalnih bolesti mnogostruko je i veoma važno. Za radnika one znače bolovanje, financijske probleme, eventualnu invalidnost; za poduzeće plaćanje bolovanja, probleme $u$ redovitom poslovanju, angažiranje nove radne snage, financijske gubitke, a za društvo u cjelini smanjenje opće produktivnosti rada i povećanje izdataka za liječenje. 
Obvezno evidentiranje ozljeda na radu, profesionalnih i drugih bolesti propisano je nizom zakonskih i podzakonskih akata, a njihova odgovarajuća analiza i interpretacija omogućuje, među ostalim, sagledavanje stanja $u$ području zaštite na radu $u$ poduzeću, izradu prijedloga novih mjera zaštite $u$ skladu s aktualnim stanjem, usporedbu sa stanjem u drugim tvrtkama, regijama i državama te ocjenu djelotvornosti i kvalitete rada poduzeća.

\section{Problematika istraživanja Scope of research}

$S$ gledišta mogućnosti usporedbe podataka o ozljedama na radu posebno su važni podaci zemalja sličnih terenskih i sastojinskih uvjeta, kao i tehnologije rada, jer oni većinom utječu na pojavu ozljeda na radu i profesionalnih bolesti radnika.

Analizirajući ozljede na radu u slovenskim privatnim šumama u razdoblju 1981-2000. godine, Medved je (2007) utvrdio da se najveći broj ozljeda dogodio pri sječi stabala i izradi drvnih sortimenata $(59,8 \%)$, zatim slijedi privlačenje $(25,9 \%)$, prijevoz $(11,6 \%)$ i ostale aktivnosti $(2,7 \%)$. Na iznimno složenu i široku problematiku zaštite na radu u slovenskom privatnom šumarskom sektoru, $\mathrm{u}$ kojem je $\mathrm{u}$ navedenom razdoblju zabilježeno čak 14 smrtnih slučajeva i 10 teških ozljeda na radu godišnje, upozoravaju Medved i Dolenšek (2000) te navode potrebu hitnoga rješavanja toga problema izradom odgovarajuće strategije. Ozljede na radu u slovenskim državnim šumama u razdoblju 1990-2005. godine analizirali su Potočnik i dr. (2009) dobivši sličnu raspodjelu ozljeda na radu po fazama rada.

U Hrvatskim šumama d.o.o. oko 600 ozljeda i tri smrtna slučaja pri radu godišnje čini stopu nesreća na radu vrlo visokom (Šporčić i Sabo 2002). Osim toga autori upozoravaju i na velik problem invalida rada koji gube radnu sposobnost uglavnom prije stjecanja prava na starosnu ili invalidsku mirovinu, a kojih je preko 900. Martinić (2007) navodi da je tvrtka Hrvatske šume zbog ozljeda na radu u razdoblju 1996-2005. godine gubila prosječno 17574 radnih dana godišnje.

Posebno su važni podaci o broju najtežih nesreća, odnosno onih sa smrtnim ishodom. Iako je broj tih nesreća u stalnom padu, pogotovo u razvijenim zemljama, one su još uvijek velik problem u šumarstvu i njihov se godišnji broj u svijetu kreće od 800 do 1000 (Garland 2018). Klun i Medved (2007) detaljno su analizirali smrtne slučajeve $u$ šest europskih zemalja. Apsolutno najveća učestalost nesreća (9,52/ mil. $\mathrm{m}^{3}$ ) zabilježena je pri neprofesionalnom radu $\mathrm{u}$
Sloveniji (1990-1994), a najmanja $\left(0,03 / \mathrm{mil}^{3} \mathrm{~m}^{3}\right)$ pri profesionalnom šumskom radu u Švedskoj (20002004) i Finskoj (1995-1999). Autori zaključuju da se razvoj sigurnosti pri radu posljednjih 25 godina vidi i u podacima o najozbiljnijim nesrećama pri šumskom radu.

Većina autora koja se bavila analizom uzroka ozljeda na radu kao glavni uzrok ističe nepravilan postupak, odnosno nedovoljnu osposobljenost radnika za sigurno i pravilno obavljanje rada te ukazuje na potrebu osnivanja profesionalnoga centra za njihovu izobrazbu (Medved 1991, Vondra 1998).

Masovnija pojava profesionalnih bolesti šumskih radnika korelira snažno s uvođenjem motornih pila u tehnološki proces sječe stabala i izrade drvnih sortimenata. Unatoč znatnim konstrukcijskim poboljšanjima, opremljenosti radnika zaštitnom opremom, obveznim zdravstvenim pregledima, opće je uvjerenje da su oštećenja sluha i vibracijska bolest i dalje prisutni te da u velikoj mjeri negativno utječu na zdravlje šumskih radnika. U Poljskoj je, na primjer, u razdoblju 2000-2009. godine registrirano čak 57 slučajeva dijagnosticiranoga gubitka sluha među šumskim radnicima (Bilski 2012).

Problem je vibracija ipak općenito puno veći. Iako se razvojem amortiziranih upravljačkih ručki i smanjenjem mase motornih pila smanjila razina vibracija prve generacije motornih pila na približno jednu desetinu, one se i dalje smatraju najteže rješivim problemom zaštite zdravlja šumskih radnika. Posljedice pretjerane izloženosti vibracijama ne samo da nisu male već su po svojoj učestalosti u ukupnim profesionalnim bolestima zabrinjavajuće (Goglia i dr. 2012). U susjednoj Republici Hrvatskoj oštećenja izazvana vibracijama sudjeluju s $13 \%$ među svim profesionalnim bolestima (Kacian 1999).

Profesionalne bolesti radnika u šumskoj proizvodnji nisu poznate samo po opasnostima koje ih karakteriziraju već i po zajedničkom djelovanju na organizam radnika. Od ukupnoga broja oštećenja zdravstvenoga stanja šumarskoga radnika sjekača njih $46 \%$ ima pojedinačne bolesti, a $54 \%$ kombinacije od dvije do pet bolesti zajedno (Rački i dr. 1990).

Unatoč značajnomu tehnološkomu razvoju šumarski se posao još uvijek smatra jednim od najopasnijih zanimanja na svijetu. Problematika zaštite na radu neopravdano se namjerno ili nenamjerno zanemaruje te usputno i površno prikazuje. Otuda motiv i potreba za ovim radom kojim će se u dužem razdoblju sagledati i analizirati stanje sigurnosti pri radu u Javnom poduzeću Šumsko-privredno društvo Zeničko-dobojskoga kantona d.o.o. Zavidovići. 


\section{Cilj rada-Aim of research}

U vezi s izloženom problematikom osnovni je cilj ovoga rada odgovarajuća analiza stanja sigurnosti pri radu u Javnom poduzeću Šumsko-privredno društvo Zeničko-dobojskoga kantona d.o.o. Zavidovići. Za ostvarenje postavljenoga cilja potrebno je obaviti ove pojedinačne zadatke:

- analizirati rad službe zaštite na radu

- utvrditi broj i strukturu ozljeda na radu

- utvrditi broj i strukturu invalidnih radnika.

Kvantitativni i kvalitativni rezultati rada predstavljat će osnovu za objektivno i točno sagledavanje stanja zaštite na radu u analiziranom poduzeću. Dobiveni rezultati identificirat će najznačajnije probleme $u$ promatranom području i kao takvi predstavljat će odlično uporište za prijedlog mjera radi popravljanja aktualnoga stanja. Osim toga rezultati rada dat će i objektivne parametre za usporedbu $\mathrm{s}$ drugim šumarskim poduzećima u Bosni i Hercegovini i/ili drugim državama.

\section{Materijal i metode Material and methods}

Javno poduzeće Šumsko-privredno društvo Zeničko-dobojskoga kantona d.o.o. Zavidovići osnovano je Odlukom Skupštine Zeničko-dobojskoga kantona 29. listopada 2003. godine. Nastalo je spajanjem svih šumarskih poduzeća, odnosno dijelova poduzeća koja su se bavila poslovima gospodarenja šumama u tom kantonu. Poduzeće gospodari državnim šumama i šumskim zemljištem na cijelom teritoriju kantona od 1. siječnja 2006. godine na ukupnoj površini od 185 084,9 ha. Godišnji je opseg sječe oko $400000 \mathrm{~m}^{3} \mathrm{i}$ realizira se s prilbližno $50 \%$ vlastitim zaposlenicima, a $50 \%$ uslugama privatnih poduzetnika.

Kao osnova za izradu odgovarajuće baze podataka i njihovu analizu poslužili su godišnja izvješća "Službe osiguranja i zaštite « poduzeća koja u skladu sa zakonskim i podzakonskim aktima, među ostalim, vodi detaljnu statistiku ozljeda na radu i profesionalnih te drugih bolesti zaposlenika. Podaci su prikupljeni za desetogodišnje razdoblje (2006-2015), a za svaku ozljedu evidentirano je ukupno 10 pokazatelja (godina, mjesec, dan i sat nastanka ozljede, zanimanje radnika, izvor ozljede, stupanj ozljede, ozlijeđeni dio tijela, dob ozlijeđenoga radnika i odsutnost s posla ozlijeđenoga radnika). Podaci o broju ozljeda na radu, ostvarenoj proizvodnji i broju zaposlenika poduzeća po godinama u okviru analiziranoga razdoblja prikazani su u tablici 1 . Za analizu dobivenih podataka i interpretaciju rezultata primijenjene su osnovne metode istraživačkoga rada: analiza, sinteza i komparacija.

Tablica 1. Pregled ozljeda u Javnom poduzeću Šumsko-privredno društvo Zeničko-dobojskoga kantona d.o.o. Zavidovići Table 1 Overview of injuries in Public Forest Management Company of Zenica-Doboj Canton Itd. Zavidovići

\begin{tabular}{|c|c|c|c|c|c|}
\hline $\begin{array}{c}\text { Godina } \\
\text { Year }\end{array}$ & $\begin{array}{c}\text { Broj } \\
\text { ozljeda } \\
\text { Number } \\
\text { of injuries }\end{array}$ & $\begin{array}{c}\text { Etat, } \mathrm{m}^{3} \\
\text { Cut } \\
\text { wood, } \mathrm{m}^{3}\end{array}$ & $\begin{array}{c}\text { Broj } \\
\text { zaposlenih } \\
\text { Number of } \\
\text { employees }\end{array}$ & $\begin{array}{c}\text { Broj ozljeda na } \\
\mathrm{m}^{3} / \text { ozljedi } \\
\mathrm{m}^{3} / \text { injury }\end{array}$ & $\begin{array}{c}\text { 1000 zaposlenih } \\
\text { Number } \\
\text { of injuries } \\
\text { per 1,000 } \\
\text { employees }\end{array}$ \\
\hline 2006 & 66 & 142790 & 1010 & 2163 & 65 \\
\hline 2007 & 40 & 170285 & 944 & 4257 & 42 \\
\hline 2008 & 71 & 169812 & 1040 & 2392 & 68 \\
\hline 2009 & 50 & 144012 & 970 & 2880 & 52 \\
\hline 2010 & 51 & 175895 & 969 & 3449 & 53 \\
\hline 2011 & 53 & 192499 & 948 & 3632 & 56 \\
\hline 2012 & 62 & 218957 & 998 & 3532 & 62 \\
\hline 2013 & 58 & 220416 & 1021 & 3800 & 57 \\
\hline 2014 & 68 & 222647 & 1036 & 3274 & 66 \\
\hline 2015 & 75 & 224790 & 976 & 2997 & 77 \\
\hline
\end{tabular}

\section{Rezultati rada $i$ rasprava Results and discussion}

\subsection{Analiza službe zaštite na radu - Analysis of occupational safety and health services}

Na osnovi Zakona o zaštiti na radu (Sl. list SR $\mathrm{BiH}$, br. 22/90) te u skladu s odredbama Zakona o radu (Sl. novine Federacije BiH, br. 43/99, br. 32/00 i br. 29/03) i Statuta poduzeća Nadzorni je odbor 2004. godine donio Pravilnik o zaštiti na radu poduzeća. Tim Pravilnikom i Pravilnikom o organizaciji i sistematizaciji radnih mjesta definirani su i organizirani poslovi iz područja zaštite na radu. $\mathrm{Na}$ razini poduzeća postoji Služba osiguranja i zaštite koju čine rukovoditelj službe te još četiri zaposlenika i čija je osnovna zadaća briga o sigurnost pri radu u poduzeću.

Najveći dio problematike zaštite na radu u poduzeću obuhvaćen je i sustavno riješen Pravilnikom o zaštiti na radu. U skladu s tim Pravilnikom na razini poduzeća, na jednu godinu, donosi se »Program mjera zaštite na radu « u kojem se konkretiziraju zadaci, rokovi, nositelji zadataka i potrebna financijska sredstva za njegovu realizaciju.

U poduzeću se provodi i stalna edukacija zaposlenika prema usvojenom Programu obrazovanja i provjere osposobljenosti zaposlenika iz zaštite na radu, a sastoji se iz teoretskoga i praktičnoga dijela 
koji se provodi na terenu po radnim mjestima zaposlenika. Za sva radna mjesta s posebnim uvjetima rada, kojih u poduzeću ima 20, napisane su upute za siguran rad i pravilnu upotrebu sredstava za rad i radne opreme.

\subsection{Ozljede na radu - Injuries at work}

U skladu s međusobnim vezama i odnosima $\mathrm{s}$ uzrocima i izvorima nastanka, odnosno stanja i kretanja ozljeda na radu kod radnika u šumarskoj proizvodnji, klasifikacija ove nepovoljne uzročno-posljedične pojave obavljena je prema više različitih obilježja njihova nastanka.

\subsubsection{Ozljede po godinama i mjesecima - Injuries by years and months}

Analiza broja ozljeda na radu po godinama i mjesecima u obuhvaćenom razdoblju služi nam za uočavanje određenih trendova. U analiziranom razdoblju zabilježene su ukupno 594 ozljede na radu, od čega tri smrtne. S obzirom na uobičajenu praksu iskazivanja tih ozljeda preko njihove brojnosti (učestalosti) po obujmu pridobivenoga drva (najčešće 1 milijun ili $10000 \mathrm{~m}^{3}$ ), ukupan broj ozljeda na radu u razdoblju 2006-2015. godine iznosio je $314 / \mathrm{mil}^{3} \mathrm{~m}^{3}$ ili 3,14/10 $000 \mathrm{~m}^{3}$, a broj smrtnih slučajeva $1,06 / \mathrm{mil}^{3} \mathrm{~m}^{3}$ pridobivenoga drva. $\mathrm{U}$ tu je analizu uključen samo drvni obujam koji je ostvaren vlastitom radnom snagom. Prema ukupnom broju ozljeda na radu od $314 / \mathrm{mil}^{3} \mathrm{~m}^{3}$ stanje je u ovom poduzeću gotovo na istoj razini kao i u ostalim šumarskim poduzećima u FBiH za koja postoje dostupni podaci (Šuškić 2013, Šubara 2015). Ipak, broj ozljeda mnogo je veći u usporedbi s razvijenim europskim zemljama ili u odnosu na susjedne države. U Hrvatskim šumama d.o.o., na primjer, broj ozljeda na radu još davne 1997. godine iznosio je 161,49/mil. $\mathrm{m}^{3}$ (Martinić 1999) uz značajno smanjenje u idućim godinama. Također, u državnim šumama u Sloveniji, na primjer, 2002. godine zabilježene su 2,2 ozljede/10 $000 \mathrm{~m}^{3}$ pridobivenoga drva (Poje 2003). Broj je smrtnih slučajeva više-manje približan kao i u državama u kojima prevladava ručno-strojna tehnologija sječe stabala i izrade drvnih sortimenata, a koji se za Hrvatsku, Sloveniju i Švicarsku kreće od 0,7 do 1,0 (Klun i Medved 2007).

Prosječan godišnji broj ozljeda na radu iznosi 59,4 pri čemu je 2007. godine zabilježen najmanji (40 ozljeda), a 2015. godine njihov najveći broj (75 ozljeda). Određeni trend povećanja broja ozljeda u posljednjih sedam godina uvjetovan je u prvom redu povećanjem obujma sječa koje je poduzeće ostvarilo svojom radnom snagom. U tom se smislu izdvajaju jedino 2006. i 2008. godina kada je, s obzirom na realizirani opseg sječa, zabilježen najveći broj ozljeda na radu uz napomenu da se broj zaposlenika $u$ analiziranom razdoblju nije značajnije mijenjao. Prema indeksu koji u odnos stavlja broj ozljeda na 1000 zaposlenika, on za analizirano razdoblje iznosi 60 ozljeda na 1000 zaposlenika. Usporedbe radi, u Hrvatskim šumama 2009. godine taj je indeks iznosio 29,4 ozljede na 1000 zaposlenih pri čemu je okarakteriziran kao iznimno visok (Martinić i dr. 2011). Raspodjela ozljeda po mjesecima prikazana je na slici 1 .

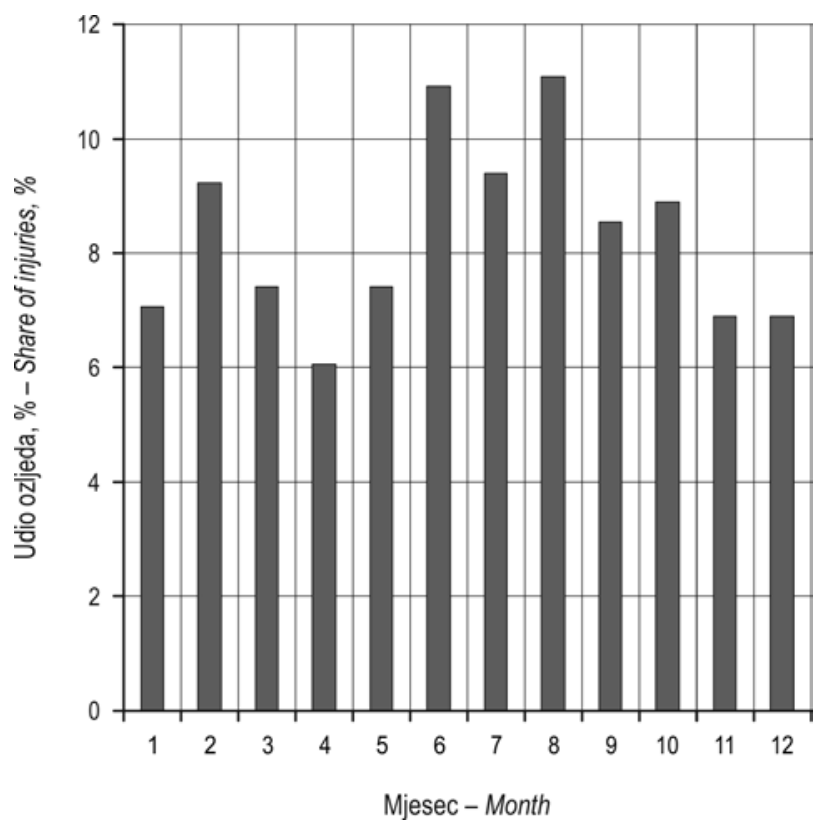

Slika 1. Raspodjela ozljeda po mjesecima Fig. 1 Distribution of injuries by months

Jasno je sa slike da veći broj ozljeda nastaje tijekom ljetnih mjeseci (VI, VII, VIII) kada su općenito bolji vremenski uvjeti te veći broj efektivnih radnih dana u mjesecu, pogotovo na radnim aktivnostima u okviru tehnološkoga procesa pridobivanja drva. Do sličnih rezultata došli su i drugi autori, s tim da se kod njih izdvaja lipanj kao mjesec s najvećim brojem ozljeda od 11,6\% (Poje 2003) te 12,61 \% (Šporčić i Sabo 2002). Najmanje ozljeda zabilježeno je u travnju $(6,06 \%)$, a općenito se manje ozljeda dogodilo u zimskim mjesecima.

\subsubsection{Ozljede prema danima i satima - Injuries by days and injuring time}

Struktura ozljeda prema danima i satima njihova nastanka prikazana je na slikama 2 i 3. 


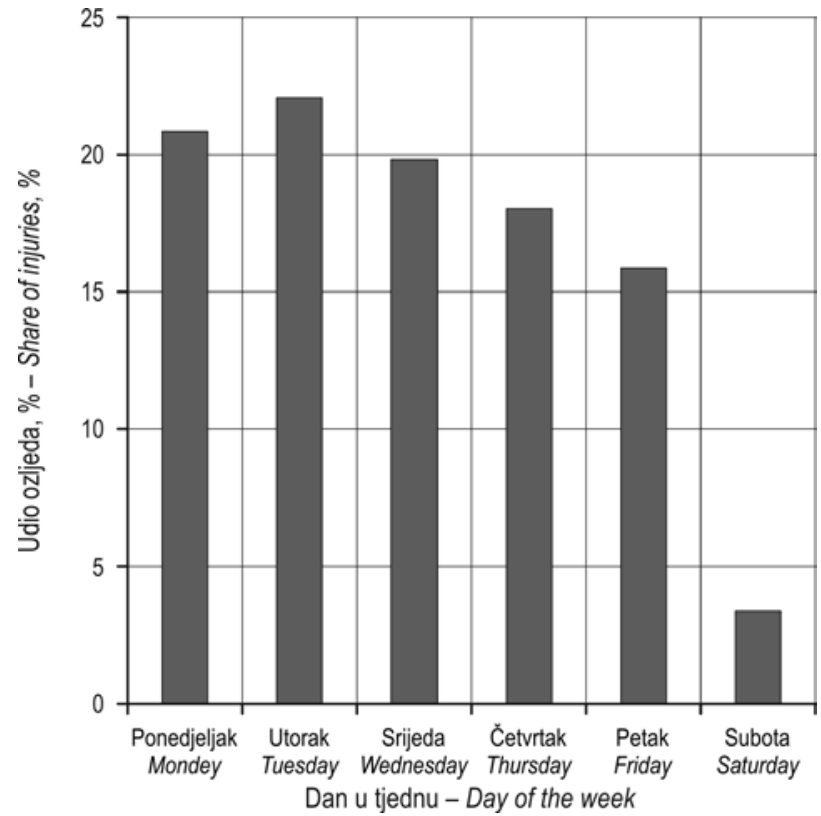

Slika 2. Raspodjela ozljeda tijekom tjedna

Fig. 2 Distribution of injuries during the week

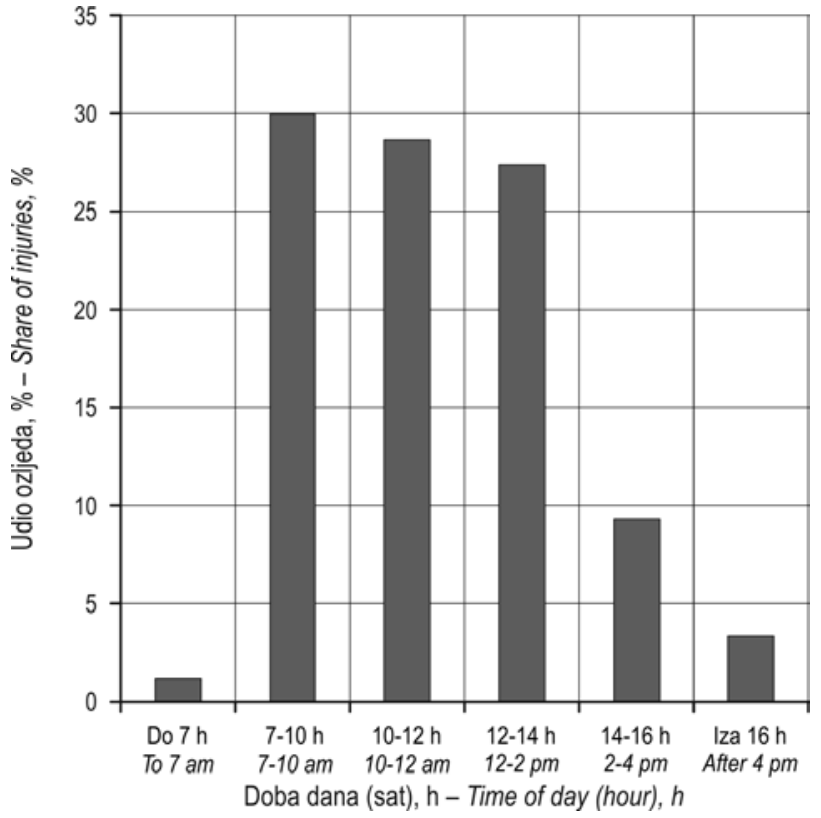

Slika 3. Raspodjela ozljeda tijekom dana

Fig. 3 Distribution of injuries during the day

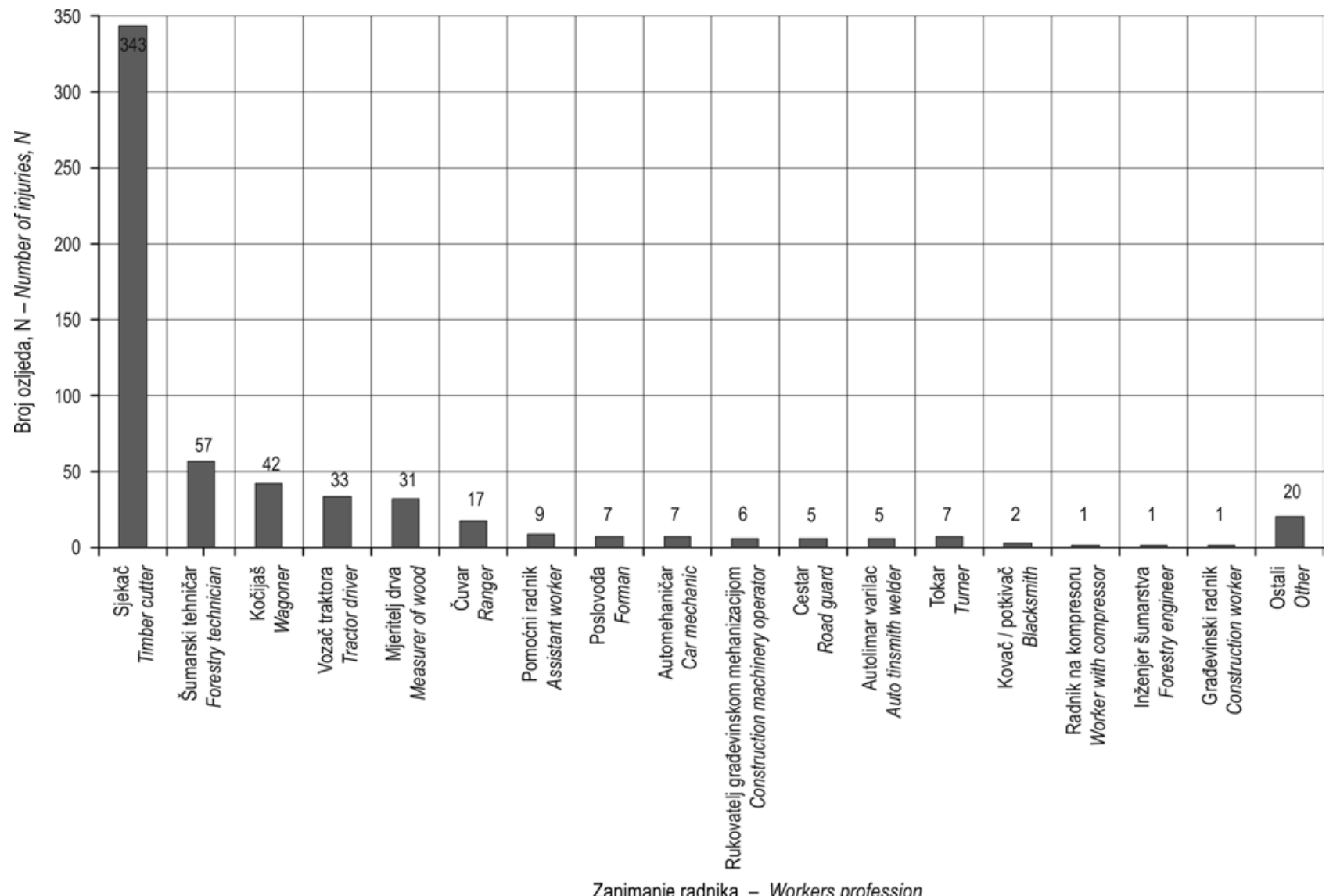

Slika 4. Raspodjela ozljeda prema zanimanju radnika

Fig. 4 Distribution of injuries by profession of workers 
Evidentno je da postoji razlika u broju ozljeda po danima u tjednu. Najmanji broj ozljeda očekivano je zabilježen u subotu - 20 ozljeda ili 3,37 \%, jer se tijekom mjeseca radi samo jedna subota. Indikativno je da se početkom radnoga tjedna događalo više ozljeda nego u ostalim danima i da se prema kraju tjedna broj ozljeda smanjuje. Kao jedino logično objašnjenje nameće se potreba za tzv. uhodavanjem u radni ritam i smanjena koncentracija radnika na početku radnoga tjedna. Sličan je trend vidljiv i na slici 3. Na početku radnoga vremena (prva tri sata) evidentirana je gotovo trećina ozljeda na radu, a vjerojatni je razlog isti. Naime, uglavnom je riječ o radnoj snazi koja dolazi iz ruralnih sredina i koja slobodno vrijeme najčešće koristi za obavljanje teških poslova u svojim domaćinstvima. Indikativno je i to da se dosta veći broj ozljeda dogodio u vrijeme odlaska s posla nego u vrijeme dolaska na posao. Kao logičan razlog nameće se umor radnika koji rezultira gubitkom koncentracije prilikom vožnje s radnoga mjesta po završetku radnoga vremena. Sličnu raspodjelu ozljeda utvrdili su i drugi autori koji su analizirali ta obilježja (Šporčić i Sabo 2002, Suchomel i dr. 2011, Šuškić 2015 i dr.).

\subsubsection{Ozljede prema zanimanju radnika - Injuries by profession of workers}

Broj ozljeda prema zanimanju radnika (profesiji) prikazan je na slici 4 .

Najviše ozljeda dogodilo se neposrednim izvršiteljima radnih operacija pridobivanja drva (sjekač, vozač traktora, kočijaš i pomoćni radnici) - 71,88\%, a najrizičnija je profesija svakako sjekač. $U$ fazi sječe i izrade dogodilo se ukupno 57,74 \% ozljeda na radu, u fazi privlačenja drveta $14,14 \%$, dok na sve ostale aktivnosti u poduzeću otpada $28,12 \%$. Prikazani rezultati većinom se podudaraju s rezultatima drugih autora (Medved 2007, Stadlman 1998, Jereb 2009).

\subsubsection{Ozljede prema uzroku (izvoru) - Injuries by source}

Uzroci ozljeda na radu mogu biti izravni (tehnič$\mathrm{ki}$, organizacijski, neodgovorno ponašanje radnika i prirodni čimbenici) i neizravni (fizički i psihički problemi radnika, socijalni problemi radnika i dispozicija radnika u odnosu na nesreće pri radu). Ipak, najčešći je slučaj da je ozljeda na radu rezultanta negativnih utjecaja više različitih uzroka te je vrlo teško točno utvrditi za pojedinu ozljedu što je bio presudan uzrok. Zbog toga, ali i zbog nekih drugih nenavedenih razloga, u poduzećima se vodi samo evidencija prema materijalnom izvoru koji je uzrokovao ozljedu. Ta je struktura prikazana na slici 5.

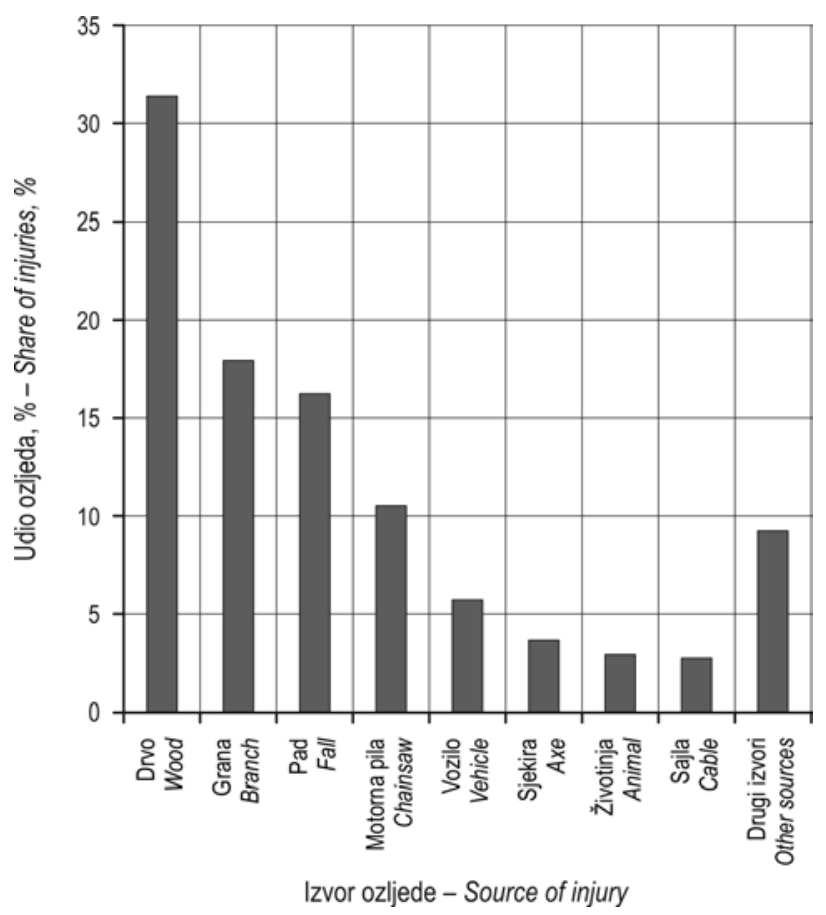

Slika 5. Raspodjela ozljeda prema izvoru

Fig. 5 Distribution of injuries by source

Analiza pokazuje da je najčešći materijalni izvor ozljede bilo drvo (31,4 \%), zatim grana $(17,8 \%)$ i pad $(16,1 \%)$. Ostali izvori ozljeda zastupljeni su u značajno manjoj mjeri. Velik udio ozljeda od drveta i grana pokazuje da je gotovo polovica ozljeda nastala kao posljedica nepravilnoga radnoga postupka i/ili nekorištenja zaštitne opreme. $S$ tim u vezi jasno je da postoji značajan prostor za njihovim smanjenjem. Relativno velik postotni udio ozljeda na radu zbog pada $(16,1 \%)$ pokazuje da je potrebno veću pažnju posvetiti izboru i nabavi adekvatne obuće za radnike u skladu s terenskim radnim uvjetima. Osim neadekvatne radne obuće vjerojatni su uzroci i nepažnja prilikom kretanja po tlu i/ili dijelovima stabla te povećan tempo rada uvjetovan željom za ostvarenjem što većega radnoga učinka. Udio ozljeda uzrokovan motornom pilom iznosi $10,44 \%$ i usporediv je s podacima zemalja gdje prevladava strojno-ručna sječa stabala i izrada drvnih sortimenata. Na primjer, u Sloveniji taj udio iznosi oko 7,5\% (Poje 2003). Relativno mali udio ozljeda uzrokovan motornom pilom uvjetovan je, $\mathrm{u}$ prvom redu, upotrebom novijih i sigurnijih sredstava za rad. Najveća starost motornih pila u vlasništvu poduzeća iznosi tri godine.

\subsubsection{Ozljede prema stupnju i ozlijeđenom dijelu tijela - Injuries by grade and injured body part}

Struktura ozljeda na radu prema tzv. zdravstveno-socijalnom kriteriju svakako je najznačajnija. U 
vezi s tim sve se ozljede razvrstavaju u tri kategorije (Kulušić 2000):

- lake ozljede koje se liječe bez trajnih zdravstvenih posljedica

- teške ozljede koje rezultiraju umanjenom radnom sposobnošću radnika u odnosu na posao koji je obavljao ili potpunom odnosno trajnom radnom nesposobnošću radnika

- smrtni slučajevi.

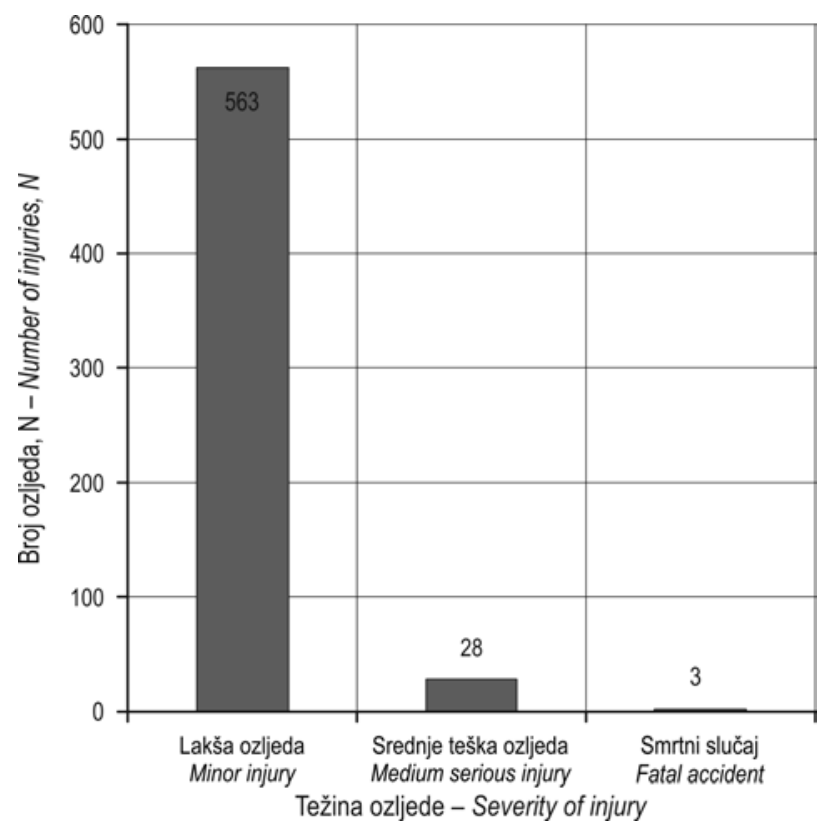

Slika 6. Raspodjela ozljeda prema težini Fig. 6 Distribution of injuries by severity

Od ukupno 594 zabilježene ozljede njih 94,78 \% klasificirano je kao lake, 4,71 \% kao srednje teške i $0,51 \%$ kao fatalne te stoga stanje $\mathrm{u}$ tom pogledu možemo ocijeniti kao zadovoljavajuće. Naime, relativni odnos evidentiranih ozljeda korelira s Heinrichovim odnosno Birdovim trianglom ozljeda, ali s nešto povoljnijim odnosom i većim udjelom lakih ozljeda.

Struktura ozljeda prema ozlijeđenom dijelu tijela većinom upućuje na moguće pravce djelovanja, odnosno mjere koje je potrebno provesti radi njihova smanjenja. Ta je struktura prikazana na slici 7 .

Ozljede ekstremiteta (noge i ruke) čine gotovo 70 $\%$ svih ozljeda na radu, a zajedno s ozljedama glave približno $90 \%$ svih ozljeda. S obzirom na prirodu poslova i sredstava za rad koja se koriste $u$ pridobivanju drva (sjekira, motorna pila, capin), možemo konstatirati da su dobiveni rezultati očekivani. Uostalom, oni snažno koreliraju s rezultatima drugih autora (Šporčić i Sabo 2002, Suchomel i dr. 2011). Može se zaključiti da bi se nabavom i korištenjem adekvatne radne obuće (cipele ili čizme s čeličnom kapicom), zaštitnih rukavica, kvalitetnijih šljemova i radne odjeće učestalost ozljeđivanja najrizičnijih dijelova tijela mogla bitno smanjiti ili bar ublažiti njihov negativan učinak.

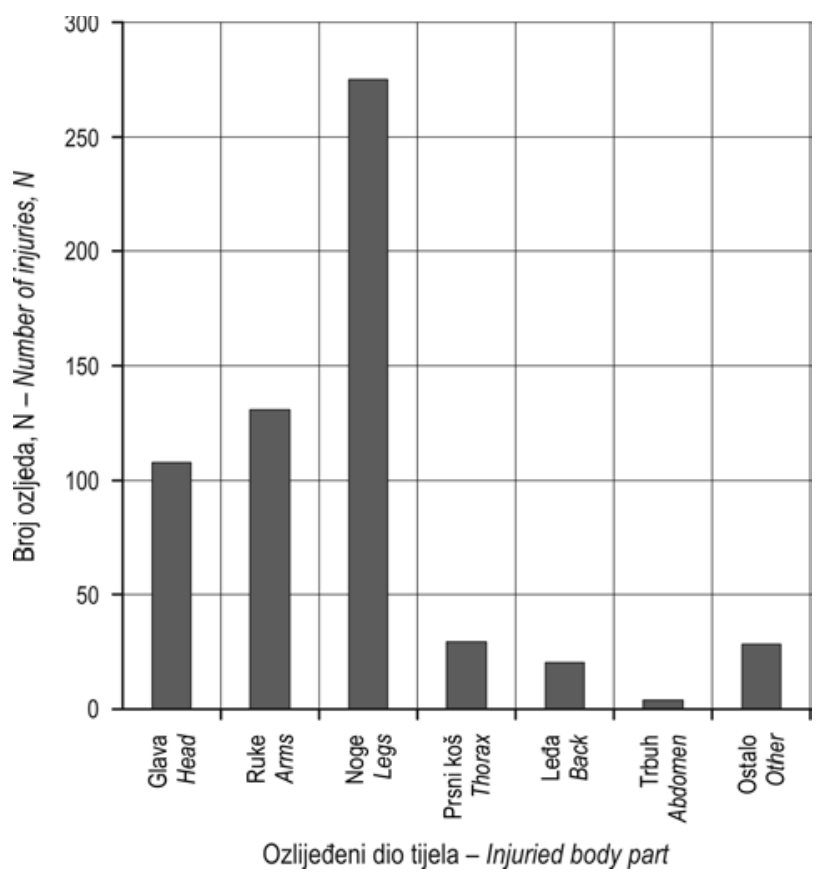

Slika 7. Raspodjela ozljeda prema ozlijeđenom dijelu tijela Fig. 7 Distribution of injuries by injured body part

\subsubsection{Ozljede prema dobi radnika - Injuries by age of workers}

Struktura ozljeda na radu prema dobi zaposlenika prikazana je na slici 8 . Uz izuzetak »najmlađe« $\mathrm{i}$ »najstarije« kategorije, svi su ozlijeđeni radnici svrstani $\mathrm{u}$ dobne razrede od 5 godina.

Najveći broj ozljeda (preko $70 \%$ ) dogodio se radnicima $\mathrm{u}$ dobi od 31 do 50 godina. $S$ obzirom na to da radnici te dobi čine najveći broj zaposlenika poduzeća, može se reći da su dobiveni rezultati sasvim očekivani i logični te da uglavnom odgovaraju rezultatima drugih autora (Čomić 1997, Šporčić i Sabo 2002, Šuškić 2013). U vezi s dobivenim rezultatima, kao pozitivnu stvar, važno je istaknuti relativno malu postotnu zastupljenost ozlijeđenih mlađih radnika. Naši rezultati u određenoj mjeri odstupaju od rezultata do kojih je u okviru svojih istraživanja došao Ranogajec (1999) koji je utvrdio da su šumarski radnici do tri godine radnoga staža nositelji čak do $45 \%$ svih ozljeda na radu. S tim u vezi za donošenje općega zaključka bilo bi potrebno napraviti detaljniju analizu koja bi uključivala i brojnost radnika po pojedinim dobnim skupinama. 


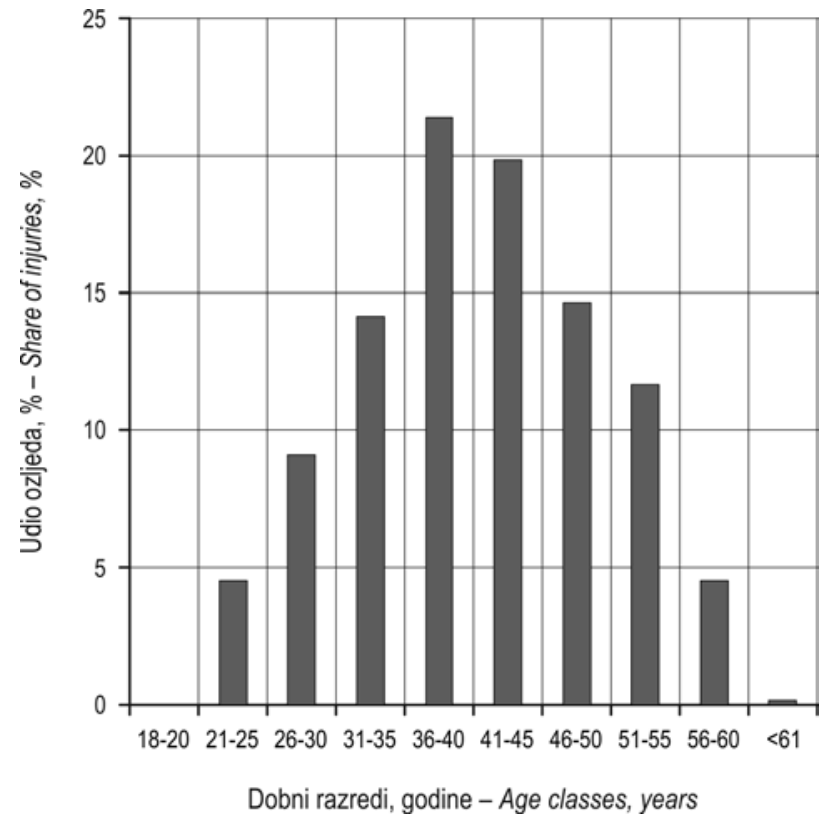

Slika 8. Raspodjela ozljeda prema dobnim razredima radnika

Fig. 8 Distribution of injuries by age categories of workers

\subsubsection{Odsutnost s posla i invalidni radnici - Sick leave and disabled workers}

Prikupljeni i analizirani podaci o trajanju i raspodjeli odsutnosti s posla (bolovanja) kao posljedica ozljeda na radu prikazani su na slici 9.

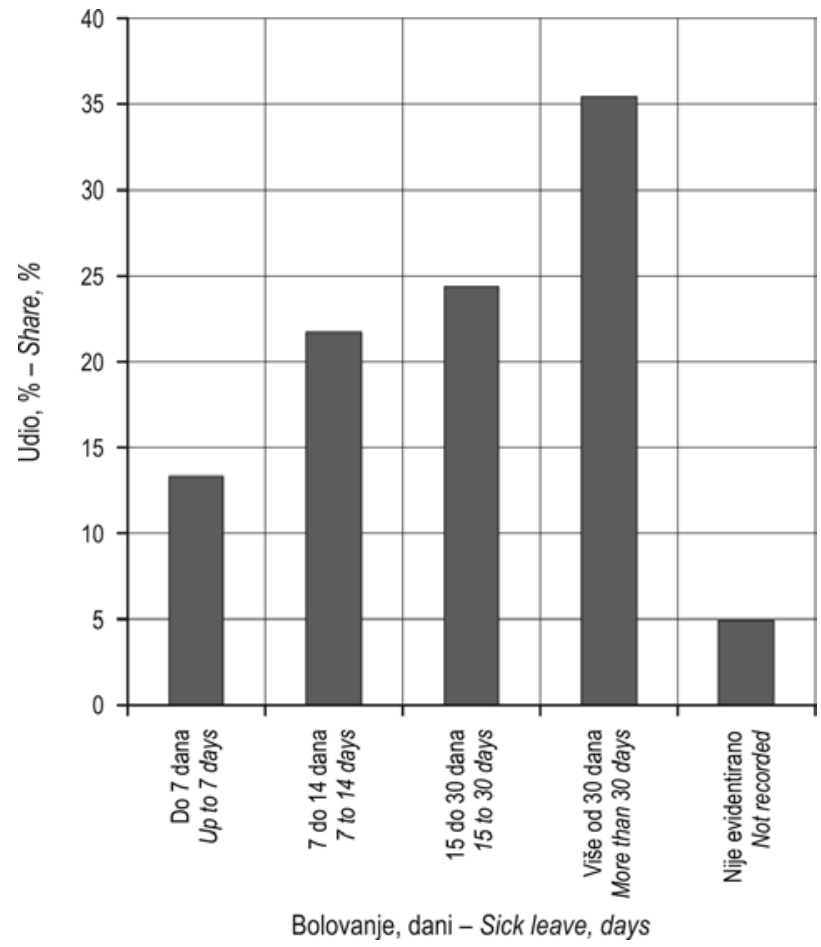

Slika 9. Raspodjela bolovanja prema dužini trajanja

Fig. 9 Distribution of sick leave by length of stay
Od ukupnoga broja ozljeda $u$ analiziranom razdoblju za njih 30, uključivo smrtne slučajeve, nije evidentirano bolovanje. Najveći broj bolovanja, nažalost, iskorišten je za najduže razdoblje (preko 30 dana). Tako dugotrajna odsutnost radnika s posla, među ostalim, ima velike višestruke negativne učinke za poduzeće. Točan broj izgubljenih radnih dana na osnovi dostupnih podataka nije bilo moguće izračunati, ali je sasvim sigurno da se radi o iznimno velikom broju, odnosno o više od 30 izgubljenih dana po ozljedi. Usporedbe radi, Potočnik i dr. (2009) utvrdili su za Sloveniju prosječno 29,27 izgubljenih dana/ozljedi, dok je taj broj u Hrvatskoj također oko 30 (Šporčić i Sabo 2002, Martinić 1999).

Ukupno su u poduzeću registrirana 133 invalida rada koji su invalidnost stekli po različitim osnovama i oni čine oko $13 \%$ ukupnoga broja zaposlenika. Najveći broj čine invalidi II. kategorije koji su prije nastanka invalidnosti bili proizvodni radnici, a nakon utvrđene invalidnosti preraspoređeni, uglavnom, na radna mjesta čuvara, pomoćnih radnika i sl. Najčešći uzrok invalidnosti radnika bila je bolest odnosno različite zdravstvene tegobe $(71 \%)$, dok je samo jedan radnik stekao invalidnost na osnovi profesionalne bolesti (slika 10).

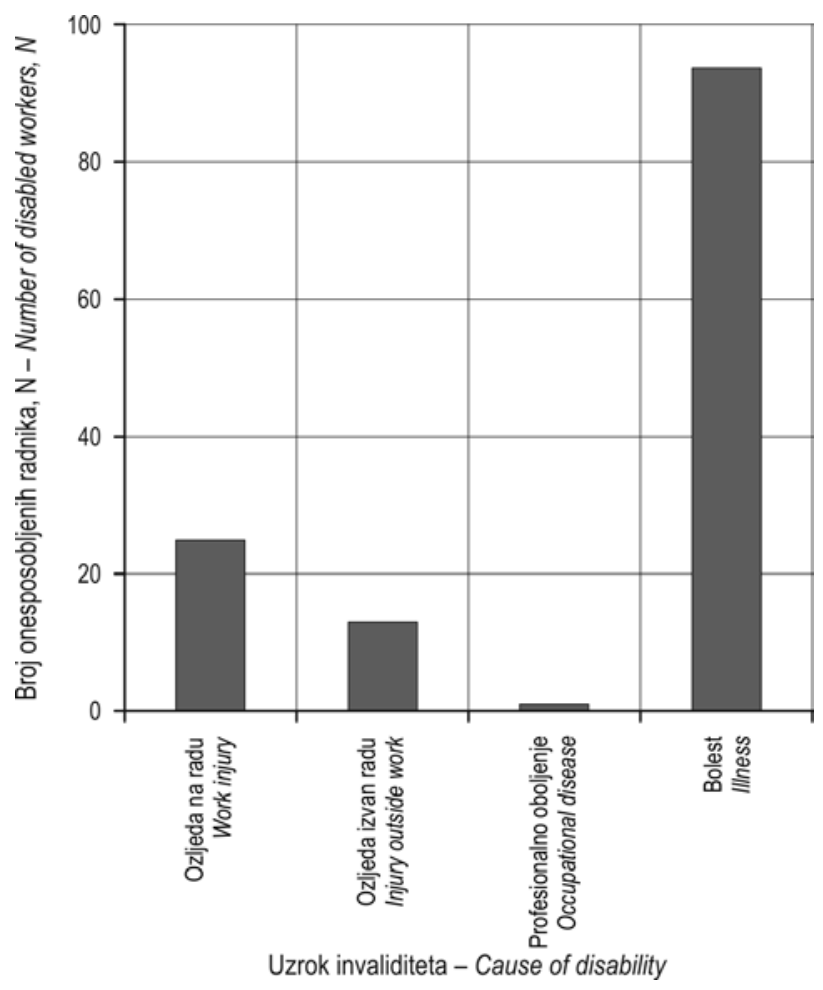

Slika 10. Raspodjela invalida rada prema uzroku invalidnosti Fig. 10 Distribution of disabled workers by cause of disability 
Udio invalida rada od $13 \%$ nešto je veći nego kod ostalih šumarskih poduzeća u Federaciji $\mathrm{BiH}$ za koje su dostupni ti podaci i koji iznosi oko $10 \%$. Problem je invalida rada veoma složen, a dodatno ga pogoršava činjenica što se većinom radi o radnicima nižega obrazovanja. Za te radnike praktično i nema mogućnosti za raspoređivanje na određene poslove koji bi odgovarali njihovoj stručnoj spremi, s jedne, te zdravstvenoj sposobnosti, s druge strane, ili su te mogućnosti veoma ograničene.

\section{Zaključci - Conclusions}

U skladu s postavljenim ciljem istraživanja, a na osnovi dobivenih rezultata, mogu se izdvojiti ovi važniji zaključci:

Javno poduzeće ŠPD Zeničko-dobojskoga kantona d.o.o. Zavidovići ima uređenu Službu osiguranja i zaštite koja se, u skladu s ograničenim kadrovskim i stručnim osobljem te propisanim zakonskim i podzakonskim aktima, brine o gotovo svim segmentima sigurnosti pri radu. Međutim, činjenica da u proteklom razdoblju nisu zabilježeni pozitivni trendovi po analiziranim ključnim pokazateljima razine sigurnosti pri radu, navodi na zaključak da rad službe uglavnom ima administrativni karakter i da programi mjera zaštite na radu nisu dali očekivane rezultate.

U analiziranom razdoblju od 2006. do 2015. godine u poduzeću su zabilježene 594 ozljede na radu ili $314 / \mathrm{mil}^{3} \mathrm{~m}^{3}$ pridobivenoga drvnoga obujma, što se, na osnovi usporedbe s drugim državama, može ocijeniti kao iznimno velik broj. Broj smrtnih slučajeva od 1,06/ mil. $\mathrm{m}^{3}$ pridobivenoga drvnoga obujma više-manje jednak je državama u kojima prevladava ručno-strojna tehnologija sječe stabala i izrade drvnih sortimenata. Prosječan broj od 60 ozljeda na 1000 zaposlenika $u$ analiziranom razdoblju enormno je velik indeks, a posebno zabrinjava odsutnost pozitivnoga trenda $\mathrm{u}$ tom pogledu.

$\mathrm{Na}$ osnovi analize raspodjele ozljeda prema najvažnijim pokazateljima (vrijeme ozljeđivanja, izvor ozljede i povrijeđeni dio tijela) može se zaključiti da postoji značajan prostor za unapređenje stanja. Velik broj ozljeda na početku radnoga dana i tjedna mogao bi se smanjiti usporavanjem radnoga tempa i sustavnim uvođenjem pauza u najrizičnijem dijelu dana. Povećani udio ozljeda uzrokovanih deblom, granama i padom upućuje na nužnost dodatne izobrazbe o pravilnim tehnikama rada, nužnost stalne upotrebe zaštitne opreme te adekvatan nadzor njezine upotrebe. Također, glavni kriterij pri izboru i nabavi radne odjeće i obuće radnika mora biti kvaliteta, a ne cijena.

Analizom invalidnosti radnika utvrđeno je da je $\mathrm{u}$ istraživanom razdoblju samo jedan radnik stekao invalidnost zbog profesionalne bolesti, dok su kod ostalih primarni uzroci bili različite zdravstvene smetnje. Ipak, iznimno velik broj invalida rada koji su, s obzirom na umanjenu radnu sposobnost, značajan problem za poslovanje poduzeća, trebao bi biti predmetom posebnih socijalno-zdravstvenih analiza.

\section{Literatura - References}

Bilski, B., 2012: Occupational Hazards and Diseases among Forestry Workers in Poland 1: 252. http://dx.doi. org/10.4172/scientificreports.252

Čomić, R., 1997: Povrede na radu i profesionalna oboljenja šumarskih radnika. Šumarski fakultet Univerziteta u Banjoj Luci, 257 str.

Garland, J. J., 2018: Accident reporting and analysis in forestry: guidance on increasing the safety of forest work. In: Proceedings of the Forest Engineering Conference, Rotorua, New Zealand, vol. 17.

Goglia, V., J. Suchomel, J. Žgela, I. Đukić, 2012: Izloženost vibracijama šumarskih radnika u svjetlu Direktive 2002/44/EC. Šumarski list 136(5-6): 283-289.

Jereb, P., 2009: Nezgode pri delu gozdarskih podjetij pred in po letu 1993. Diplomsko delo, Univerza v Ljubljani, Biotehniška fakulteta, Ljubljana, 1-79.

Kacian, N., 1999: Occupational diseases in Croatia. Work and Safety 3(1): 83-89.

Klun, J., M, Medved, 2007: Fatal accidents in forestry in some European countries. Croatian Journal of Forest Engineering 28(1): 55-62.

Kulušić, B., 2000: Iskorištavanje šuma. Rukopis, Šumarski fakultet Univerziteta u Sarajevu, 1-356.

Landekić, M., 2010: Organizacijska kultura i sigurnost pri radu u hrvatskom šumarskom sektoru. Šumarski list 134(11-12): 613-622.

Marković, Ž. D., 1989: Sociologija zaštite na radu. IMP Književne novine, Beograd, 361 str.

Martinić, I., 1999: Sigurnost i zdravlje šumskih radnika poticaj za njihovo unapređenje u Hrvatskoj. Šumarski list 123(5-6): 201-210.

Martinić, I., 2007: Varovanje zdravja in varnost pri delu v obdobju tranzicije v gozdarskem sektorju Hrvaške. Gozdarski vestnik 65(2): 67-73.

Martinić, I., M. Landekić, M. Šporčić, M. Lovrić, 2011: Šumarstvo na pragu Evropske unije - koliko smo spremni 
na području sigurnosti pri šumskom radu. Croatian Journal of Forest Engineering 32(1): 431-441.

Medved, M., 1991: Vključevanje lastnikov gozdov v gozdno proizvodnjo. Magistrsko delo, Biotehniška fakulteta Univerza v Ljubljani, 1-179.

Medved, M., 2007: Nezgode v zasebnih gozdovih v Sloveniji - plakat. Dan varnosti pri delu v gozdu, Jurij (SLO), Langegg (A), 17. 11. 2007.

Medved, M., M. Dolenšek, 2000: Nezgode v kmetijstvu in gozdarstvu - problem evidenc. IV. Mednarodna konferenca Globalna varnost, Bled, Slovenija, 18-21. junij 2000, Zbornik referatov, Zavod za varstvo pri delu, Ljubljana, 81-90.

Poje, A., 2003: Nezgode pri delu v gozdarskih izvajalskih podjetjih Slovenije v letu 2002. Gozdarski vestnik 61(9): 360-371.

Potočnik, I., T. Pentek, A. Poje, 2009: Severity Analysis of Accidents in Forest Oparations. Croatian Journal of Forest Engineering 30(2): 171-184.

Rački, Z., M. Vukelić, G. Rinčić, A. Štimac, 1990: Neke karakteristike vibracione bolesti kod sjekača Gorskog Kotara. Znanstveno savjetovanje: Životni i radni uvjeti proizvodnih radnika u šumarstvu i njihov utjecaj na zdravstveno stanje i socio-ekonomski položaj, Radovi Šumarskog instituta 25(1): 157-164.

Ranogajec, B., 1999: Sigurnost i zdravlje šumskih radnika - poticaj za njihovo unapređenje u Hrvatskoj (2). Šumarski list 123(7-8): 339-343.
Stadlmann, H., 1998: Varnost pri delu v avstrijskem gozdarstvu. Gozdarski vestnik 56(9): 390-396.

Suchomel, J., K. Belanová, M. Vlčková, 2011: Analysis of occupational accidents occurrence in Slovakia forestry. International Scientific Conference Technology and Ergonomics in the Service of Modern Forestry, Krakow, Poland, 26-29 June 2011, University of Agriculture in Krakow, 93-105.

Šporčić, M., A. Sabo, 2002: Ozljeđivanje radnika u hrvatskom šumarstvu tijekom razdoblja 1991-2000. Šumarski list 126(5-6): 261-271.

Šubara, Dž., 2015: Povrede na radu i profesionalna oboljenja šumarskih radnika preduzeća šumarstvo »Prenj« d.d. Konjic. Završni rad, Šumarski fakultet Univerziteta u Sarajevu, Sarajevo, 1-57.

Šuškić, A., 2013: Povrede na radu i profesionalna oboljenja šumarskih radnika ŠPD/ŠGD »Srednjobosanske šume/Šume Središnje Bosne« d.o.o. Donji Vakuf. Završni rad, Šumarski fakultet Univerziteta u Sarajevu, Sarajevo, 1-52.

Vondra, V., 1998: Promišljanje šumskih radnika o vlastitoj profesiji. Mehanizacija šumarstva 23(3-4): 101-116.

Zakon o zaštiti na radu, Sl. list SR BiH, br. 22/90.

Zakon o radu, Sl. novine Federacije BiH, br. 43/99, 32/00, $29 / 03$. 


\begin{abstract}

\section{Analysis of Safety at Work in Forestry of the Federation BEH - Case Study}

Injuries at work and occupational diseases are a reliable indicator for assessing the state of occupational safety. The aim of this paper was to conduct an appropriate analysis of the state of safety at work in JP Šumsko privredno društvo Zeničko-dobojskoga kantona d.o.o. Zavidovići (Public Forest Management Company of Zenica-Doboj Canton ltd. Zavidovici). The subject of analysis were injuries at work, occupational and other diseases of forestry workers in the period 2006-2015. Injuries were analyzed based on 10 different indicators. During the analyzed period, 594 injuries were reported, three of which were fatal. The highest number of accidents was recorded in the harvesting process (66.3\%), while the most hazardous occupation was that of timber cutter (57.7\%). Wood and branches were the most common material cause of injury (49.3\%), and workers' extremities (legs and arms) were the most commonly injured body part (70\%). The highest number of injuries was recorded at the beginning of the working week and day. According to the number of injuries by the amount of cut wood (314/mil. $\left.\mathrm{m}^{3}\right)$, as well as an index of 60 injuries per 1,000, employees safety at work can be assessed as extremely unsatisfactory.
\end{abstract}

Keywords: injuries at work, forest workers, occupational diseases, safety at work

Primljeno (Received): 11. 7. 2019.

Prihvaćeno (Accepted): 20. 9. 2019.
Adresa autorâ - Author's addresses:

Prof. dr. sc. Jusuf Musić*

e-pošta: j.music@sfsa.unsa.ba

Prof. dr. sc. Velid Halilović

e-pošta: v.halilovic@sfsa.unsa.ba

Prof. dr. sc. Ahmet Lojo

e-pošta: a.lojo@sfsa.unsa.ba

Šumarski fakultet Univerziteta u Sarajevu

Zagrebačka 20

71000 Sarajevo

BOSNA I HERCEGOVINA

Prof. dr. sc. Mario Šporčić

e-pošta: sporcic@sumfak.hr

Šumarski fakultet Sveučilišta u Zagrebu

Svetošimunska 25

10000 Zagreb

HRVATSKA

Ajdin Đonlagić, mag. ing. silv.

e-pošta: ajdin_djonlagic@hotmail.com

Bukva b.b.

74260 Tešanj

BOSNA I HERCEGOVINA

${ }^{*}$ Glavni autor - Corresponding author 
